\title{
Comparative Study of the Reactivity of Clay Earth Materials for the Production of Compressed Earth Blocks in Ambient Conditions: Effect on Their Physico-Mechanical Performances
}

\author{
Tarmangue Dime1, Seick Omar Sore ${ }^{1,2}$, Philbert Nshimiyimana ${ }^{*}$, Adamah Messan1, Luc Courard ${ }^{3}$ \\ ${ }^{1}$ Laboratoire Eco-Matériaux et Habitats Durables (LEMHaD), Institut International d'Ingénierie de l'Eau et de l'Environnement \\ (Institut 2iE), Rue de la Science, Ouagadougou, Burkina Faso \\ ${ }^{2}$ Département Génie Civil, Institut Universitaire de Technologie, Université Nazi Boni (UNB), Bobo-Dioulasso, Burkina Faso \\ ${ }^{3}$ Urban and Environmental Engineering (UUE), Université de Liège (ULiege), Liège, Belgium \\ Email: *philbert.nshimiyimana@2ie-edu.org
}

How to cite this paper: Dime, T., Sore, S.O., Nshimiyimana, P., Messan, A. and Courard, L. (2022) Comparative Study of the Reactivity of Clay Earth Materials for the Production of Compressed Earth Blocks in Ambient Conditions: Effect on Their Physico-Mechanical Performances. Journal of Minerals and Materials Characterization and Engineering, 10, 43-56.

https://doi.org/10.4236/jmmce.2022.101004

Received: December 26, 2021

Accepted: January 24, 2022

Published: January 27, 2022

Copyright $\odot 2022$ by author(s) and Scientific Research Publishing Inc. This work is licensed under the Creative Commons Attribution International License (CC BY 4.0).

http://creativecommons.org/licenses/by/4.0/

\section{(c) (i) Open Access}

\begin{abstract}
This study assesses the reactivity of four (04) different types of clayey earthen materials (Kamboinsé, Pabré, Saaba, and Kossodo) with $\mathrm{Ca}(\mathrm{OH})_{2}$, analytical lime ( $\mathrm{AL}$ ) versus lime residu (LR), in ambient conditions. The effect of the stabilization of the earth with the LR was also studied on the performances of compressed earth blocks (CEB). The lime content varied from $0 \%$ to $20 \%$ with respect to the mass of dry earth material. The analysis of the reactivity and physico-mechanical properties were respectively carried out on the solutions of the mixtures (earth $+\mathrm{LR}$ and earth $+\mathrm{AL}$ ) and CEB (earth $+\mathrm{LR}$ ). The mixtures were cured between 0 and 60 days at the ambient temperature of laboratory $\left(30^{\circ} \mathrm{C} \pm 5^{\circ} \mathrm{C}\right)$. The results showed that the reactivity of the clayey earth materials with $\mathrm{AL}$ is comparable to that with the $\mathrm{LR}$. At the same time, this reactivity improved the physical and mechanical properties of stabilized CEB depending on the type of earth material, lime content and curing time. The maximum values of the dry compressive strength, observed for each material stabilized with $20 \% \mathrm{LR}$, are 6 and $7 \mathrm{MPa}$ (Kamboinsé), 8.8 and $9.3 \mathrm{MPa}$ (Pabré), 6 and 6.5 MPa (Saaba), 8.8 and 9.7 MPa (Kossodo) respectively at curing time of 28 and 45 days. The structural efficiency of CEB was also improved which implies that, in the current conditions, the stabilization of earth materials using LR allows to produce the CEB for potential applications in wall masonry.
\end{abstract}




\section{Keywords}

Clayey Earth, Compressed Earth Brick, Analytical Lime, Lime Residu, Physical and Mechanical Properties

\section{Introduction}

In recent years, the earth material has known a fairly significant recovery for its use for the construction of habitats [1]-[7]. This is due to its multiple advantages for the construction of sustainable housing. Previous studies have been carried out for the stabilization of earth using binders such as cement, lime, rice husk ash, ... for improving its performances [3] [4] [5] [8].

Recent studies have mainly focused on the stabilization of CEB using lime residue (LR), a rejected by-product from the manufacture of acetylene, rich in $\mathrm{Ca}(\mathrm{OH})_{2}$. This has shown to be a beneficial stabilizing agent as a replacement for cement [4] [7] [8] [9]. The stabilization effect of lime is also remarkable because of its pozzolanic reaction with the clayey earth. It should also be noted that this reaction depends essentially on the curing temperature and the type of earth material [9] [10] [11]. The use of lime can allow to improve the physical, mechanical and thermal properties of CEB produced with the reactive clayey earth. It has little effect on the earth less rich in clay [9]. The LR is therefore effective and can provide the improvement of the performances comparably or even better than cement for the production of CEB.

The selection of the earth material for the production of CEB (stabilized) is mainly done by considering the plasticity and grain size of the soil. However, recent studies have shown that it is important to consider the reactivity of earth for appropriate use in the production of CEB stabilized with chemical binders [8]. The previous study [8] proposed an evaluation of the reactivity of mixture solutions of clayey earth and LR (crushed and sieved on $125 \mu \mathrm{m}$ ) cured at controlled temperature $\left(40^{\circ} \mathrm{C} \pm 2^{\circ} \mathrm{C}\right)$. This study had limitations in terms of the use of LR, which contains less than $50 \%$ of $\mathrm{Ca}(\mathrm{OH})_{2}$, the maturation at the relatively high temperature, as well as grinding the LR to a relatively smaller fineness [8]. Another study has shown the possibility to correlate the mechanical and physical properties of CEBs, through the compressive strength and abrasion resistance [12]. However, this correlation was established on the basis of only one type of clayey earth material and still requires the validation on other types of materials and mixtures.

The present study evaluates the reactivity of different clay materials with lime (analytical lime versus lime residue) and the influence of the addition of lime residue $(<400 \mu \mathrm{m})$ on the physico-mechanical performances of CEB stabilized and cured at room temperature of the laboratory in Burkina Faso $\left(30^{\circ} \mathrm{C} \pm 5^{\circ} \mathrm{C}\right)$ in order to compare with the influence previously obtained with lime residue $(<125$ $\mu \mathrm{m})$. In addition, the present study attempts to establish the correlation between compressive strength and abrasion resistance of CEB produced with different 
types of clay earth. This was intended to confirm the possibility to establish a non-crushing test for the evaluation of the performances of CEB.

\section{Materials and Experimental Methods}

\subsection{Characteristics of Materials}

Four different types of clay materials were collected from quarries located around Ouagadougou in Burkina Faso: Kamboinsé (K), Pabré (P), Saaba (S) and Kossodo (Ko). The geographic, chemical, physical and mineralogical characteristics of these materials have been reported in previous studies [8] [9]. The materials from Kamboinsé contain 60\% kaolinite, 20\% quartz; Pabré contains 30\% of kaolinite, 55\% of quartz; Kossodo contains 40\% kaolinite, 30\% quartz; and Saaba contains $70 \%$ kaolinite, $20 \%$ quartz. The earth materials also contain traces of goethite, hematite and K-Feldspar. The lime residue contains about $50 \%$ of portlandite $\left(\mathrm{Ca}(\mathrm{OH})_{2}\right)$ and carbonates, while analytical lime contains mainly $\mathrm{Ca}(\mathrm{OH})_{2}$.

\subsection{Production of Solutions and Evaluation of Reactivity of Earth}

The production of solutions aimed to assess the behavior and the evolution of the reaction between the earth and lime (LR and $\mathrm{AL}$ ) in order to compare their respective effects. The solutions were produced by mixing earth, lime $(10 \%$ and $20 \%$ of the mass of the earth) and distilled water. It involves taking a known quantity of earth $(10 \mathrm{~g})$ and adding the percentages of lime (10\% and $20 \%$ equivalent respectively to $1 \mathrm{~g}$ and $2 \mathrm{~g}$ ) to each earth material and mix with distilled water (100 g). Subsequently, control solutions containing only lime (1 $\mathrm{g}$ and $2 \mathrm{~g}$ ) and distilled water $(100 \mathrm{~g})$ were produced. The earth material was taken from the undersize of $400 \mu \mathrm{m}$ and the lime (LR) was crushed and sieved through 400 $\mu \mathrm{m}$. The mixtures were well mixed to allow a good homogeneity and cured at room temperature in the laboratory $\left(30^{\circ} \mathrm{C} \pm 5^{\circ} \mathrm{C}\right)$ for 0 to 60 days, before each measurement of the reactivity. The evolution of the reactivity was monitored by measuring the electrical conductivity of the solutions using a $\mathrm{pH}$ enomenal device MU $6100 \mathrm{~L}$ multiparameter lab conductimeter equipped with CO 11 conductivity probe and $\mathrm{pH}$ electrode (Figure 1).

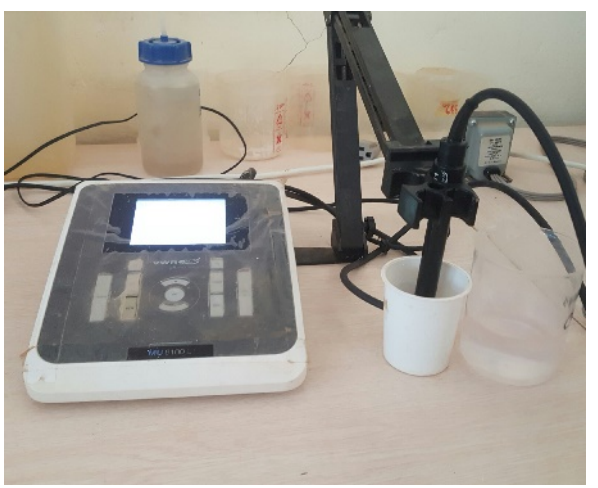

Figure 1. Monitoring of the reactivity of solutions cured at room temperature in the laboratory $\left(30^{\circ} \mathrm{C}\right.$ $\pm 5^{\circ} \mathrm{C}$ ) by electrical conductivity measurement. 


\subsection{Production and Evaluation of the Physico-Mechanical Proper Ties of CEB}

Different mix design based on each type of earth material and $0 \%, 10 \%$ and $20 \%$ lime ( $\mathrm{LR}<400 \mu \mathrm{m}$ ) were used to produce the CEB and determine their characteristics. For each earth or mixture of the earth and lime, an appropriate amount of water was added to produce humid mixtures. The water content was determined by static compaction, and taking into consideration the water demand of $0 \%-20 \%$ lime [9]. The water content was equivalent to $17 \%-22 \%(\mathrm{~K}), 16 \%-$ $20 \%(\mathrm{P}), 13 \%-17 \%(\mathrm{Ko})$, and $18 \%-22 \%(\mathrm{~S})$. The appropriate amount of humid materials was compressed in mold $\left(295 \times 140 \times 95 \mathrm{~mm}^{3}\right)$ of a Terstaram press machine to mold the CEB. The CEB were cured in polyethylene bags in order to retain the moisture and to facilitate the reaction between lime and earth (Figure 2). The curing was carried out in the laboratory at room temperature $\left(30^{\circ} \mathrm{C} \pm\right.$ $5^{\circ} \mathrm{C}$ ) for 28 and 45 days.

After maturation, the $\mathrm{CEB}$ were dried at $40^{\circ} \mathrm{C} \pm 2^{\circ} \mathrm{C}$ until constant mass before testing their performances. The tests were carried out on the bulk density, resistance to abrasion and resistance to the compression in dry conditions [13]. The bulk density was determined by the ratio of the masse of the dry sample and the geometric volume. The coefficient of abrasion was determined by the ratio of abraded area and the weight loss. The abrasion was carried using a metallic brush loaded with $3 \mathrm{~kg}$ on the surface of the sample $(2.5 \times 29.5 \mathrm{~cm})$ subjected to 60 cycles of abrasion. The compressive strength was tested on the stack of two halves of CEBs, in dry and wet conditions after immersion in water for $2 \mathrm{~h}$, using hydraulic press, model Proeti safr, equipped with a $300 \mathrm{kN}$ capacity load cell at loading rate of $0.2 \mathrm{~mm} / \mathrm{s}$.

\section{Results and Discussions}

\subsection{Reactivity of Earth Materials in Ambient Conditions}

This study made it possible to assess the reactivity of earth in ambient conditions of curing. It was achieved by measuring the electrical conductivity (EC) of solutions of mixtures of different earth and lime. In general, a decrease in the value of the EC was noticed over the curing time for all mixtures containing earth and $10 \%$ or $20 \%$ lime: LR or AL (Figures 3-6). In the first three days, there was no significant change in the EC of solutions. It is therefore from the $7^{\text {th }}$ day that the net decrease in EC was observed in the solutions containing earth and lime (LR or $\mathrm{AL})$. The decrease of the $\mathrm{EC}$ is related to the reaction between earth and lime, which results in the consumption of $\mathrm{Ca}^{2+}$ and $\mathrm{OH}^{-}$initially dissolved from the lime: $\mathrm{Ca}(\mathrm{OH})_{2}$ [8]. The evolution of the $\mathrm{EC}$ is comparable for the solutions containing the LR and AL. This allows to confirm that the reaction between the earth and LR is comparable to that with AL.

When the reaction starts, the mix solutions containing AL have slightly higher EC than the solutions containing RL. This can be related to the fact that the AL contains more $\mathrm{Ca}(\mathrm{OH})_{2}$ than the RL. The decrease of the EC continues until the 


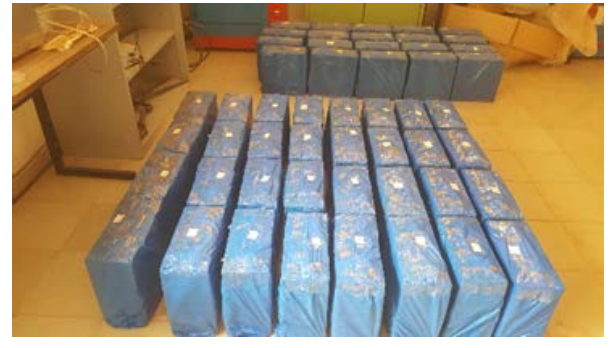

Figure 2. Maturation of covered CEB under the production humidity at room temperature in the laboratory $\left(30^{\circ} \mathrm{C} \pm 5^{\circ} \mathrm{C}\right)$.

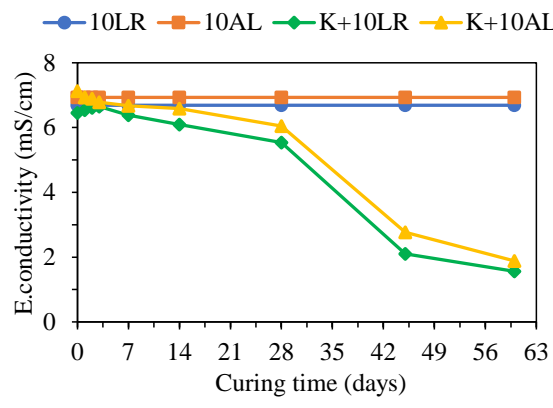

(a)

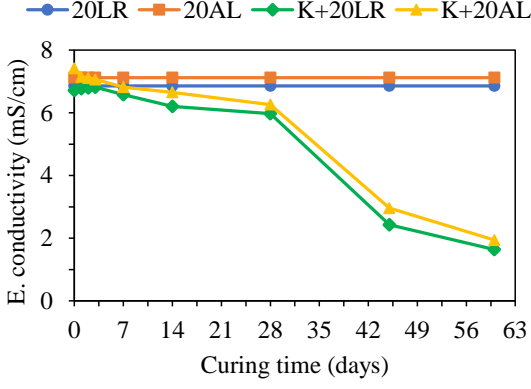

(b)

Figure 3. Evolution of the electrical conductivity of solutions containing earth (Kamboinsé: K) and (a) $10 \%$ or (b) $20 \%$ of lime (AL and LR).

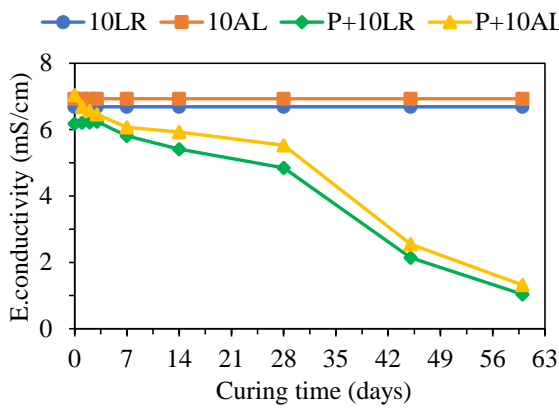

(a)

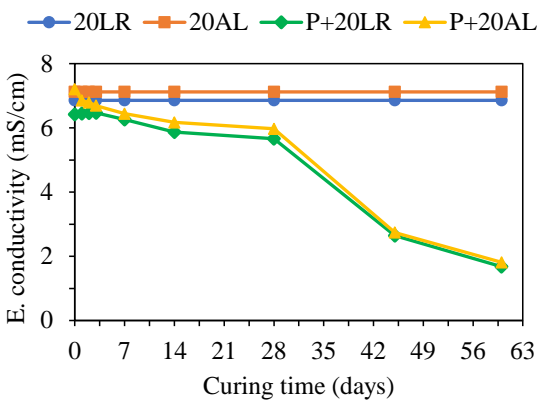

(b)

Figure 4. Evolution of the electrical conductivity of solutions containing earth (Pabré: P) and (a) $10 \%$ or (b) $20 \%$ of lime (AL and LR).

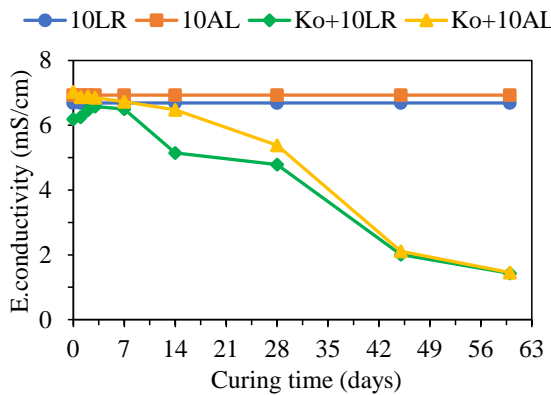

(a)

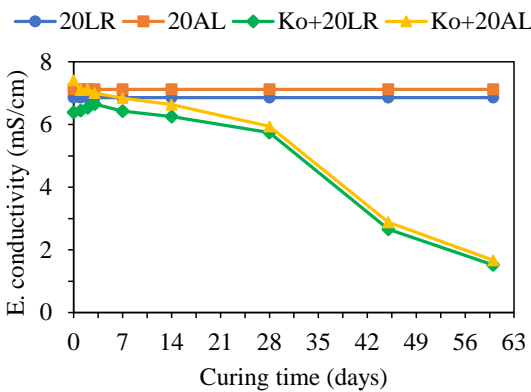

(b)

Figure 5. Evolution of the electrical conductivity of solutions containing earth (Kossodo: Ko) and (a) $10 \%$ or (b) $20 \%$ of lime (AL and LR). 


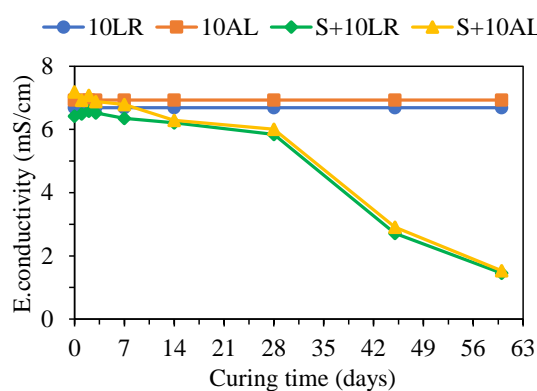

(a)

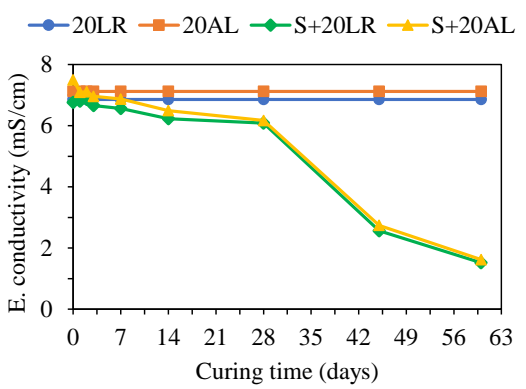

(b)

Figure 6. Evolution of the electrical conductivity of solutions containing earth (Saaba: S) and (a) $10 \%$ or (b) $20 \%$ of lime (AL and LR).

$60^{\text {th }}$ day, with the highest kinetics observed between the $28^{\text {th }}$ and $45^{\text {th }}$ day. However, the control solutions (distilled water and lime) did not undergo any significant change of EC up to the $60^{\text {th }}$ day of curing. This explains the absence of the interaction between distilled water and lime, but rather confirms the interaction between earth and lime through the pozzolanic reaction.

On the one hand, the value of EC reached $5.5 \mathrm{mS} / \mathrm{cm}(\mathrm{K}), 5 \mathrm{mS} / \mathrm{cm}(\mathrm{P}, \mathrm{Ko})$ and $6 \mathrm{mS} / \mathrm{cm}(\mathrm{S})$ for solutions containing $10 \% \mathrm{LR}$; on the other hand, the value of EC were $6 \mathrm{mS} / \mathrm{cm}(\mathrm{K}, \mathrm{S}), 5.5 \mathrm{mS} / \mathrm{cm}(\mathrm{P}, \mathrm{Ko})$ for $10 \% \mathrm{AL}$, after 28 days. These values of EC decreased until reaching the value of $2-2.5 \mathrm{mS} / \mathrm{cm}$ after 45 days, then the value of $1-2 \mathrm{mS} / \mathrm{cm}$ after 60 days. For the solutions containing $20 \%$ of lime, a similar evolution was observed, but with the values of the EC slightly higher than with $10 \%$ lime. The EC of the solutions containing the $20 \%$ LR or $\mathrm{AL}$ and different earth has changed from $6 \mathrm{mS} / \mathrm{cm}$ at the $28^{\text {th }}$ day to $2-2.5$ $\mathrm{mS} / \mathrm{cm}$ at the $45^{\text {th }}$ day and $1.5-2 \mathrm{mS} / \mathrm{cm}$ at the $60^{\text {th }}$ day.

This gradual decrease in EC is due to the gradual consumption of $\mathrm{Ca}^{2+}$ and $\mathrm{OH}^{-}$during the pozzolanic reaction between clay materials and lime [8]. The values of $\mathrm{EC}$ of solutions containing $\mathrm{AL}$ are slightly higher than those containing LR due to a higher content of $\mathrm{Ca}(\mathrm{OH})_{2}$, responsible for the reaction, in the AL than in the LR. Nevertheless, the EC evolves similarly for the solutions containing AL or LR. Thus, this makes it possible to confirm that the reactivity of LR is comparable to that of AL and would make it possible to evaluate the reactivity of clay materials [8]. It is also noteworthy that the curing of the solutions at room temperature in the laboratory $\left(30^{\circ} \mathrm{C} \pm 5^{\circ} \mathrm{C}\right)$ allowed to reach the results similar to those obtained previously during the curing at controlled and slightly elevated temperature $\left(40^{\circ} \mathrm{C} \pm 2^{\circ} \mathrm{C}\right)$ [8]. This suggests that it is not really necessary to increase the temperature of maturation, by heating to $40^{\circ} \mathrm{C}$. On the contrary, it would therefore be advisable to limit the maturation solutions at room temperature in the laboratory.

\subsection{Physico-Mechanical Properties of CEB}

\subsubsection{Bulk Density}

The decrease in the value of the bulk density of CEB was noticed with the gradual addition of LR (Figure 7). The density decreases from a value of 1494 to 
$1445 \mathrm{Kg} / \mathrm{m}^{3}$ for the materials from Kamboinsé; from 1873 to $1818 \mathrm{Kg} / \mathrm{m}^{3}$ for Pabré; from 1825 to $1757 \mathrm{Kg} / \mathrm{m}^{3}$ for Kossodo and from 1471 to $1438 \mathrm{Kg} / \mathrm{m}^{3}$ for Saaba, for the CEB cured at 28 days (Figure 7 (a)). For the CEB cured at 45 days, the values of density are roughly similar, ranging from 1492 to $1450 \mathrm{Kg} / \mathrm{m}^{3}$ (Kamboinsé), 1873 to $1675 \mathrm{Kg} / \mathrm{m}^{3}$ (Pabré), 1825 to $1785 \mathrm{Kg} / \mathrm{m}^{3}$ (Kossodo) and 1481 to $1424 \mathrm{Kg} / \mathrm{m}^{3}$ (Saaba) (Figure $7(\mathrm{~b})$ ). This decrease in density is partly explained by the increase in the demand of the production water with the addition of LR to the earth. The decrease of the bulk density can also be related to the low density of the lime with respect to that of the earth material. The smallest density values are observed for Kamboinsé and Saaba materials that required a higher amount of water than other materials.

\subsubsection{Resistance to Abrasion}

The CEB without stabilizers (0\% LR) have a surface behavior proving their sensitivity to abrasion. They have abrasion coefficients $(\mathrm{Cb})$ of $1 ; 9 ; 2$ and $1 \mathrm{~cm}^{2} / \mathrm{g}$ respectively for Kamboinsé, Pabré, Saaba and Kossodo for all the curing times (Figure 8). They are therefore not acceptable, except for Pabré, according to the standard [13] which stipulates that the minimum values of $\mathrm{Cb}$ must be respectively 2, 5 and $7 \mathrm{~cm}^{2} / \mathrm{g}$ for the different classes of CEB (CEB20, CEB40, CEB60). CEB without stabilizer produced with material from Pabré have a coefficient enabling them to meet the requirements of the standard.

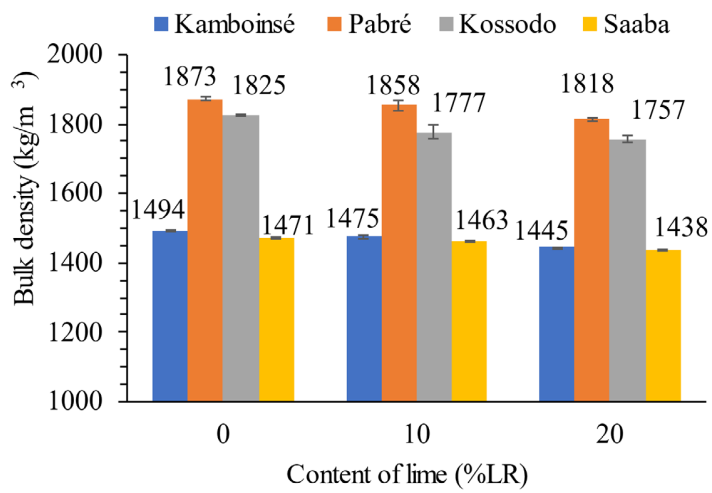

(a)

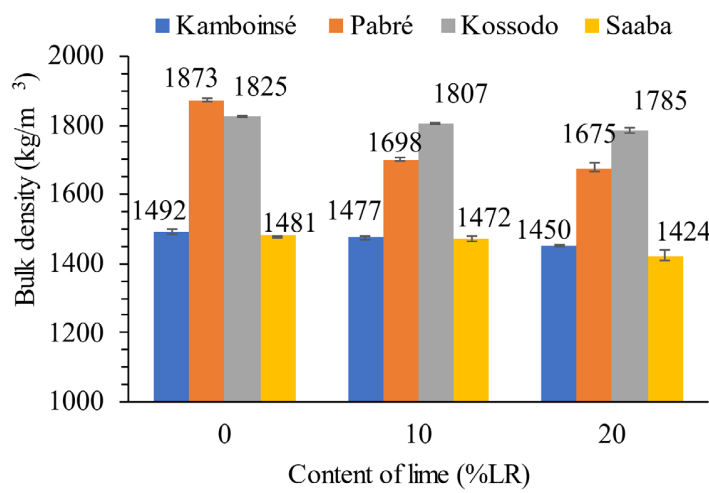

(b)

Figure 7. Bulk density of CEB cured for (a) 28 days, (b) 45 days. 


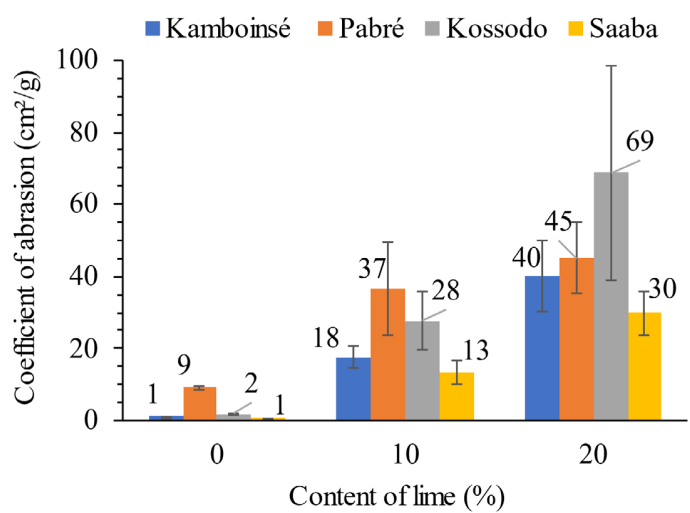

(a)

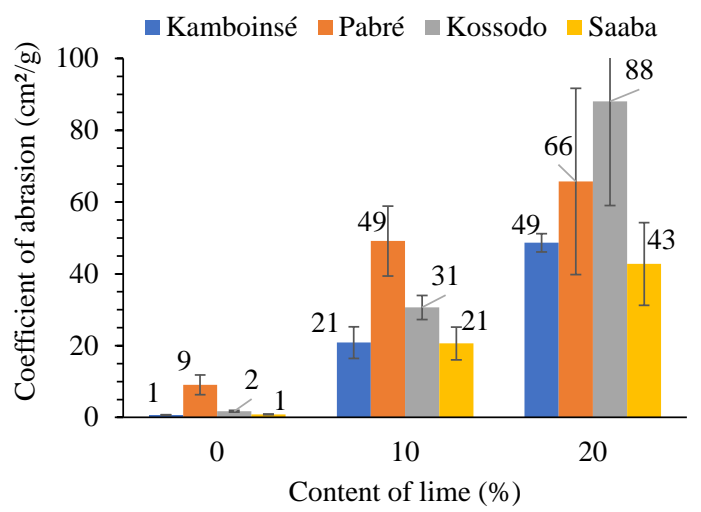

(b)

Figure 8. Abrasion coefficient for CEB matured cured for (a) 28 days, (b) 45 days.

For stabilized CEB ( $10 \%$ and $20 \%$ LR), the abrasion resistance gradually improved with the addition of LR until reaching the values of $18,37,28$, and 13 $\mathrm{cm}^{2} / \mathrm{g}(10 \% \mathrm{CR})$ and 40, 45, 69, and $30 \mathrm{~cm}^{2} / \mathrm{g}(20 \% \mathrm{LR})$ respectively for Kamboinsé, Pabré, Kossodo and Saaba cured for 28 days. For curing at 45 days, the abrasion coefficient reaches the values of $21,49,31$, and $21 \mathrm{~cm}^{2} / \mathrm{g}(10 \% \mathrm{LR})$ and $49,66,88$, and $43 \mathrm{~cm}^{2} / \mathrm{g}$ (20\% LR) respectively for Kamboinsé, Pabré, Kossodo and Saaba (Figure 8). This increase of the abrasion resistance can be related to the pozzolanic reaction between earth materials and lime, which results in the hardening effect on the surface of CEB.

\subsubsection{Resistance to Dry Compression}

The comparison between the unstabilized CEB and stabilized CEB shows that the resistance to the compression of CEB stabilized with $10 \%$ and $20 \%$ LR has gradually improved. For the same content of LR, the values of the compressive strength of CEB cured at 45 days are slightly higher than those obtained at 28 days. The values of the compressive strength were $0.4,2.6,1,0.6 \mathrm{MPa}$ respectively for the non-stabilized CEB produced with materials from Kamboinsé, Pabré Kossodo, and Saaba. The compressive strength increased to reach 5 and $5.9 \mathrm{MPa}$ (for Kamboinsé), 7.9 and 8.8 MPa (Pabré), 7.7 and 8.8 MPa (Kossodo), and 5 
and $6 \mathrm{MPa}$ (Saaba) respectively stabilized with 10\% and 20\% LR and cured for 28 days (Figure 9(a)). These values reached 6.2 and $7 \mathrm{MPa}$ (Kamboinsé), 8.4 and 9.3 MPa (Pabré), 8.6 and 9.9 MPa (Kossodo) and 5.6 and 6.5 MPa (Saaba) respectively stabilized with $10 \%$ and $20 \%$ of LR and cured for 45 days (Figure 9(b)).

Under these conditions, the stabilization of CEB with $0 \%$ to $20 \%$ corresponds to the increase of the strength in the range of order of 13 times ( 0.4 to $5.9 \mathrm{MPa}$ ) for the material from Kamboinsé, 2 times (2.6 to 5.9 MPa) for Pabré, 8 times (1 to $8.8 \mathrm{MPa})$ for Kossodo and 10 times $(0.6$ to $6 \mathrm{MPa})$ for Saaba after the curing time of 28 days. This increase is 16 times ( 0.4 to $7 \mathrm{MPa}$ ) for Kamboinsé, 3 times (2.5 to $9.3 \mathrm{MPa}$ ) for Pabré, 9 times $(1.1$ to $9.9 \mathrm{MPa}$ ) for Kossodo and 10 times (0.6 to $6.5 \mathrm{MPa}$ ) for Saaba cured for 45 days.

This improvement of the strength is due to the reactivity of the various clay materials with the LR [7] [9]. These results confirm the pozzolanic reactivity observed with the mix solutions of the different clay materials and the lime. This reaction leads to the formation of cementitious products, such as hydrates of calcium silicates and calcium aluminates, responsible for the increase in the resistance to the compression of stabilized CEB [7]. It implies that the more the material is reactive, the more it achieves a higher increase of the resistance. In the current curing condition $\left(30^{\circ} \mathrm{C} \pm 5^{\circ} \mathrm{C}\right)$, the material of Kamboinsé which has the highest ratio of the increase of the resistance at 28 days (13 times) and 45 days (16 times) is the most reactive; followed by Saaba (10 times), Kossodo (8 and 9 times) and Pabré ( 2 and 3 times). It is also noticed that the highest ratio of increase of resistance is reached within 28 days of maturation, beyond which it does not improve too much. This is quite different to the results previously reported for the same materials cured in controlled condition $\left(40^{\circ} \mathrm{C} \pm 2^{\circ} \mathrm{C}\right)$. In that condition, the materials from Saaba reached the highest performances in terms of both the kinetics of the reactivity and improvement of the compressive strength, followed by Kossodo, Kamboinse and Pabré [8]. This confirms that the conditions of the production highly affect the performances of CEBs [9].

The increase in resistance to the compression observed in the present study is comparable to that previously obtained for CEB stabilized with LR $(<125 \mu \mathrm{m})$,

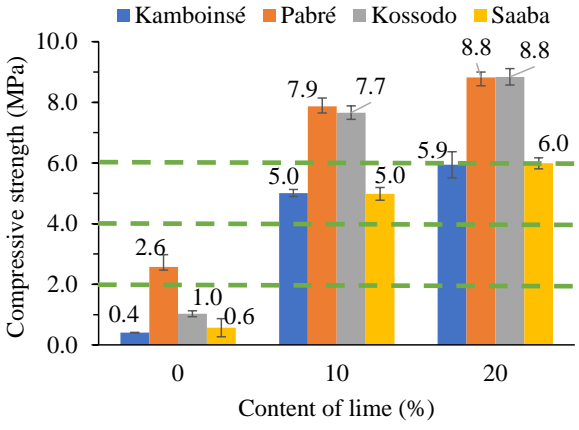

(a)

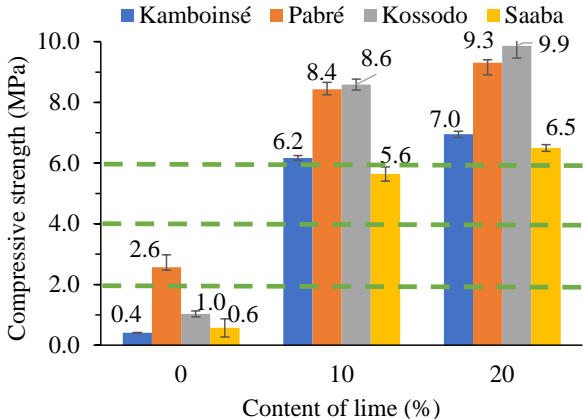

(b)

Figure 9. Compressive strength of matured CEB at (a) 28 days, (b) 45 days. 
and cured under the controlled conditions, at a slightly elevated temperature $\left(40^{\circ} \mathrm{C} \pm 2^{\circ} \mathrm{C}\right)$ and for 45 days [8]. This implies that the CEB can be produced by stabilization with $10 \%$ or $20 \%$ of LR (fineness $<400 \mu \mathrm{m}$ ) and cured in ambient conditions for 28 or 45 days to achieve the required resistance. Indeed, the use of this finesse of LR has led to a compressive strength of CEB that exceed the value of $4 \mathrm{MPa}$ (with $10 \% \mathrm{LR}$ and at 28 days of curing) required for their application in the construction of the walls of one-storey building and reach the value of 6 $\mathrm{MPa}$ (with $20 \% \mathrm{LR}$ and at 45 days of curing) for the walls of two-storey building [14].

\subsection{Correlation between Abrasion Coefficient and Dry Compressive Strength}

A possible correlation exists between the compressive strength and the abrasion coefficient. The importance of this correlation is to be able to estimate the resistance to the compression of CEB from the coefficient of resistance to abrasion. The abrasion coefficient is easier to test by abrasion of the surface, without crushing the sample, using simple and less expensive means; while it is more difficult to test the compressive strength which requires more sophisticated and expensive, and destructive equipment.

Figures 10(a) and Figure 10(b) respectively show the relationships between the coefficient of abrasion: $\mathrm{Cb}\left[\mathrm{cm}^{2} / \mathrm{g}\right]$ and the compressive strength: $\mathrm{Rc}[\mathrm{MPa}]$ of CEB from all materials and cured for 28 and 45 days. This makes it possible to propose an approximate relationship to correlate the two parameters $\left(\mathrm{Cb}\left[\mathrm{cm}^{2} / \mathrm{g}\right]\right.$ and $\mathrm{Rc}[\mathrm{MPa}]$ ) for each type of earth material and each curing time. It was thus obtained a general relation with two parameters (A and B) expressed by Equation 1. In this equation, $A$ varies from 0.69 to 0.84 and $B$ varies from 0.59 to 0.67 for different materials and cured for 28 days; and A varies from 0.55 to $0.85 ; \mathrm{B}$ varies from 0.58 to 0.70 for different materials and cured for 45 days. Figure 10 (c) shows the average correlation $\left(\mathrm{Rc}=0.71 \times \mathrm{Cb}^{0.64}\right)$ between $\mathrm{Cb}\left[\mathrm{cm}^{2} / \mathrm{g}\right]$ and $\mathrm{Rc}[\mathrm{MPa}]$ for all types of materials and for any curing time.

$$
\mathrm{Rc}=\mathrm{A} \times \mathrm{Cb}^{\mathrm{B}}
$$

This is the evidence of the existence of a strong correlation $\left(R^{2}=0.84\right.$ to 0.99$)$ between the resistance to compression and the resistance to abrasion of the CEB. However, this correlation would strongly depend on the type of the materials, in terms of the values of parameters A and B. Nevertheless, these results will make it possible to estimate the compressive resistance as a function of the abrasion resistance by simply determining these two parameters for the material of concern.

\subsection{Structural Performances of CEB}

Structural performance of CEB was assessed through a coefficient structural efficiency (CSE). The CSE is an important physico-mechanical parameter in the evaluation of the contribution of resistance and density of CEB to their load 


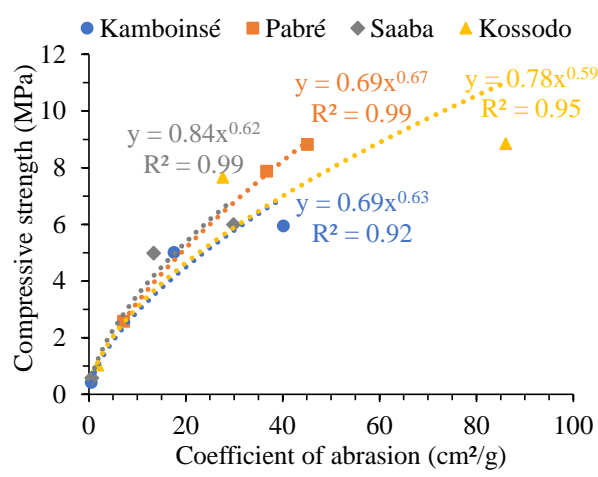

(a)

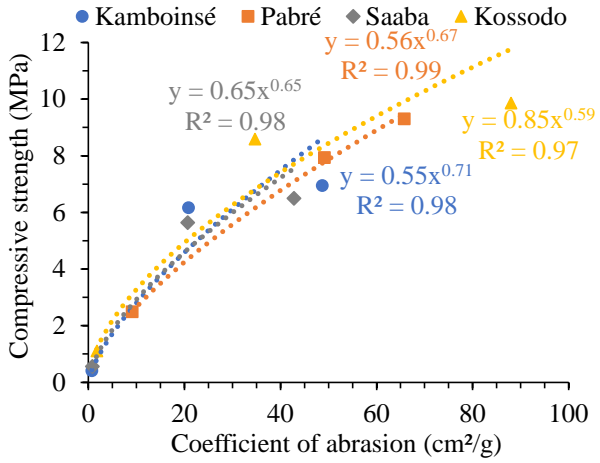

(b)

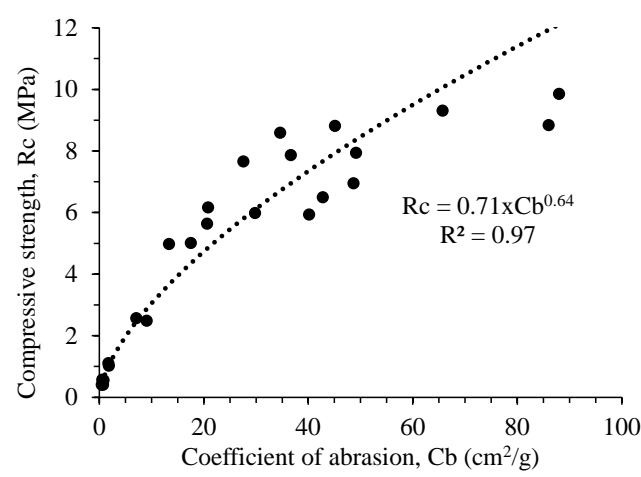

(c)

Figure 10. Correlation of the compressive strength and coefficient of abrasion for CEB cured at (a) 28 days, (b) 45 days and (c) 28 and 45 days.

bearing capacity in building construction. The CSE is determined by the ratio between the dry compressive strength and the bulk density of CEB [15] [16]. This parameter makes it possible to evaluate the improvement of the ability of CEB to carry the load in construction by maximizing its resistance while minimizing its own weight (bulk density). It is noted that the use of $\operatorname{LR}(<400 \mu \mathrm{m})$ as a stabilizer has significantly improved the CSE.

The values of the CSE of unstabilized CEB ( $0 \%$ CR) were 274, 1372, 564 and $387 \mathrm{~Pa} \cdot \mathrm{m}^{3} / \mathrm{kg}(\mathrm{J} / \mathrm{kg})$ respectively for the materials of Kamboinsé, Pabré, Kossodo and Saaba. These values respectively increased to 3397 and $4111 \mathrm{~J} / \mathrm{kg}, 4237$ and $4851 \mathrm{~J} / \mathrm{kg}, 4310$ and $5033 \mathrm{~J} / \mathrm{kg}$, and 3403 and $4166 \mathrm{~J} / \mathrm{kg}$ for CEB stabilized with 10 and $20 \%$, for the curing time of 28 days (Figure 11(a)). This corresponds respectively to an increase of the order of 11 and 14 times, 2 and 3 times, 7 and 8 times, and 9 and 11 times for CEB stabilized with 10\% and 20\% LR compared to non-stabilized CEB ( $0 \%$ LR), for the curing time of 28 days. The values of the CSE increased slightly higher for CEB cured at 45 days (Figure 11(b)). They respectively increased by 14 and 16 times, 3 and 3 times, 7 and 9 times, and 9 and 11 times for the CEB stabilized with $10 \%$ and $20 \%$ compared to unstabilized CEB. This increase of the CSE at 45 days can be considered comparable to the increase observed at 28 days.

This implies that CEB stabilized with a higher LR content (20\%) can relatively 


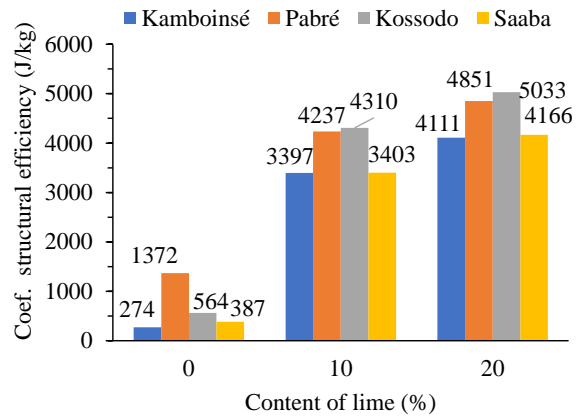

(a)

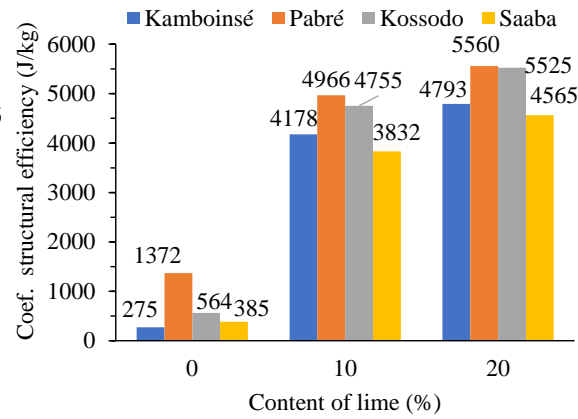

(b)

Figure 11. Coefficient of structural efficiency of CEB cured for (a) 28 days, (b) 45 days.

bear more loads since they are lighter than CEB stabilized with a lower LR content $(10 \%)$, while both have comparable resistance to the compression. These results confirm those previously obtained by [15] using LR $(<125 \mu \mathrm{m})$ on the one hand and LR in combination with rice husk ash (RHA) on the other hand for the stabilization of only one type of earth.

\section{Conclusions}

The results presented in this article are part of the valorization of (by-) products locally available in Burkina Faso, more precisely the lime residue used at a coarser fineness $(<400 \mu \mathrm{m})$. The study aimed to determine the reactivity of clay materials with analytical lime (AL) in order to compare it with that obtained with residual lime (LR). The study also assessed the influence of the addition of LR on the physico-mechanical performances of stabilized CEB. At the end of the various tests, the following conclusions are adopted.

1) The consumption of residual lime (LR) by different clay materials is comparable to that of analytical lime (AL) resulting in a decrease in the electrical conductivity of solutions during the curing. This confirms the reactivity of these clay materials with LR in ambient curing conditions.

2) The density of CEB decreases with the increase in the stabilizing content in the order of 1495 to $1420 \mathrm{~kg} / \mathrm{m}^{3}$ for the materials from Kamboinsé and Saaba and from 1875 to $1750 \mathrm{~kg} / \mathrm{m}^{3}$ for Pabré and Kossodo.

3) The coefficient of abrasion of CEB increases with the addition of the stabilizer (20\% LR), in the order of 0.5 to $40 \mathrm{~cm}^{2} / \mathrm{g}$ for Saaba and Kamboinsé and 1.9 to $88 \mathrm{~cm}^{2} / \mathrm{g}$ for Pabré and Kossodo. It is slightly higher for CEB cured for 45 compared to those cured for 28 days.

4) The compressive strength of CEB increases with the addition of LR (20\%), in the range of 0.5 to $7 \mathrm{MPa}$ for Kamboinsé and Saaba and 1 to $10 \mathrm{MPa}$ for Pabré and Kossodo. It is slightly higher for CEB cured for 45 days than those cured at 28 days. This proves an improvement in the resistance of CEB, resulting from the reactivity observed under these conditions. The CEB stabilized with LR is potentially useful in the construction of multi-storey buildings.

5) The correlation, with two parameters $A$ and $B\left(R c=A \times C b^{B}\right)$, was con- 
firmed between the coefficient of abrasion: $\mathrm{Cb}\left[\mathrm{cm}^{2} / \mathrm{g}\right]$ and the compressive strength: Rc [MPa] for all materials and curing times. This can potentially be used to estimate the quality and mechanical performance of CEB, depending on the type of materials used for their production.

Moreover, these results are satisfactory because they not only correspond to the requirements of the standards but also correspond to the results obtained by other research in the field of construction. This makes it possible to deduce that the fineness of lime used $(<400 \mu \mathrm{m})$ is recommendable for the production of $\mathrm{CEB}$ at any scale and reach the required performances. However, future studies should evaluate the physico-mechanical parameters of CEBs (density, compressive strength, abrasion resistance) of these clays stabilized with AL.

\section{Acknowledgements}

This work was supported by the "Académie de la Recherche et de I Enseignement Supérieur" of the "Fédération Wallonie-Bruxelles (Belgium)-Commission de la Coopération au Développement (ARES-CCD) as part of an international research and development project "improving the quality of earth-based housing in Burkina Faso, PRD2016-2021”.

\section{Conflicts of Interest}

The authors declare no conflicts of interest regarding the publication of this paper.

\section{References}

[1] Sajanthan, K., Balagasan, B. and Sathiparan, N. (2019) Prediction of Compressive Strength of Stabilized Earth Block Masonry. Advances in Civil Engineering, 2019, Article ID: 2072430. https://doi.org/10.1155/2019/2072430

[2] Murmu, A.L. and Patel, A. (2018) Towards Sustainable Bricks Production: An Overview. Construction and Building Materials, 165, 112-125. https://doi.org/10.1016/j.conbuildmat.2018.01.038

[3] Nshimiyimana, P., Miraucourt, D., Messan, A. and Courard, L. (2018) Calcium Carbide Residue and Rice Husk Ash for Improving the Compressive Strength of Compressed Earth Blocks. MRS Advances, 3, 2009-2014. https://doi.org/10.1557/adv.2018.147

[4] Moussa, H.S., Nshimiyimana, P., Hema, C., Zoungrana, O., Messan, A. and Courard, L. (2019) Comparative Study of Thermal Comfort Induced from Masonry Made of Stabilized Compressed Earth Block vs. Conventional Cementitious Material. Journal of Mineral and Materials Characterization and Engineering, 7, 385-403. https://doi.org/10.4236/jmmce.2019.76026

[5] Sore, O.S., Messan, A., Prud'homme, E., Escadeillas, G. and Tsobnang, F. (2018) Stabilization of Compressed Earth Blocks (CEB) by Geopolymer Binder Based on Local Materials from Burkina Faso. Construction and Building Materials, 165, 333-345. https://doi.org/10.1016/j.conbuildmat.2018.01.051

[6] Hema, C.M., Van Moeseke, G., Evrad, A., Courard, L. and Messan, A. (2017) Vernacular Housing Practices in Burkina Faso: Representative Models of Construction in Ouagadougou and Walls Hygrothermal Efficiency. Energy Procedia, 122, 535-540. 
https://doi.org/10.1016/j.egypro.2017.07.398

[7] Nshimiyimana, P., Messan, A., Zhao, Z. and Courard, L. (2019) Chemico-Microstructural Changes in Earthen Building Materials Containing Calcium Carbide Residue and Rice Husk Ash. Construction and Building Materials, 216, 622-631. https://doi.org/10.1016/j.conbuildmat.2019.05.037

[8] Nshimiyimana, P., Fagel, N., Messan, A., Wetshondo, O.D. and Courard, L. (2020) Physico-Chemical and Mineralogical Characterization of Clay Materials Suitable for Production of Stabilized Compressed Earth Blocks. Construction and Building Materials, 241, 118097. https://doi.org/10.1016/j.conbuildmat.2020.118097

[9] Nshimiyimana, P., Moussa, H.S., Messan, A. and Courard, L. (2020) Effect of Production and Curing Conditions on the Performance of Stabilized Compressed Earth Blocks: Kaolinite vs. Quartz-Rich Earthen Material. MRS Advances, 5, 1277-1283. https://doi.org/10.1557/adv.2020.155

[10] Al-Mukhtar, M., Lasledj, A. and Alcover, J.F. (2010) Behaviour and Mineralogy Changes in Lime-Treated Expansive Soil at $20^{\circ} \mathrm{C}$. Applied Clay Science, 50, 191-198. https://doi.org/10.1016/j.clay.2010.07.023

[11] Al-Mukhtar, M., Lasledj, A. and Alcover, J.F. (2010) Behaviour and Mineralogy Changes in Lime-Treated Expansive soil at 50 ${ }^{\circ}$ C. Applied Clay Science, 50, 199-203. https://doi.org/10.1016/j.clay.2010.07.022

[12] Nshimiyimana, P., Messan, A. and Courard, L. (2021) Hydric and Durability Performances of Compressed Earth Blocks Stabilized with Industrial and Agro by-Product Binders: Calcium Carbide Residue and Rice Husk Ash. Journal of Materials in Civil Engineering, 33, 04021121. https://doi.org/10.1061/(ASCE)MT.1943-5533.0003745

[13] PR XP P13-901 (2017) Blocs de terre comprimée pour murs et cloisons-Définitions-Spécifications-Méthodes d'essai-Conditions de réception, AFNor, Saint-Denis La Plaine Ce-dex.

[14] CDI and CRATerre-EAG (1998) Compressed Earth Blocks: Standards guide-Technology series N 11. Boubekeur, S., Houben, H., Doat, P., D’Ornano, S., Douline, A., Garnier, P., Guillaud, H., Joffroy, T., Rigassi, V., Editors. Brussels.

[15] Nshimiyimana, P., Messan, A. and Courard, L. (2020) Physico-Mechanical and Hygro-Thermal Properties of Compressed Earth Blocks Stabilized with Industrial and Agro by-Product Binders. Materials, 13, 3769. https://doi.org/10.3390/ma13173769

[16] Turco, C., Paula Junior, A.C., Teixeira, E.R. and Mateus, R. (2021) Optimisation of Compressed Earth Blocks (CEB) Using Natural Origin Materials: A Systematic Literature Compilation Review. Construction and Building Materials, 309, 125140. https://doi.org/10.1016/j.conbuildmat.2021.125140 